\title{
The impact of man-made accidents and catastrophes in the stable functioning of industrial enterprises on the quality of life of the population and socio-economic development
}

\author{
Lyudmila Kamdina, ${ }^{1, *}$, Olga Simchenko ${ }^{2}$, Valery Grakhov ${ }^{2}$, Alexander Suntsov ${ }^{2}$, and Evgeny \\ Chazov $^{2}$ \\ ${ }^{1}$ Chelyabinsk State University, Bratiev Kashirinyh, str., 129, 454001 Chelyabinsk, Russia \\ ${ }^{2}$ Izhevsk State Technical University named after M.T. Kalashnikov, Studencheskaya, str. 7, \\ 426069 Izhevsk, Russia
}

\begin{abstract}
The article considers the quality of life of population and the impact of man-made accidents and disasters during stable functioning of industrial enterprises. The author offered to take into account the influence of anthropogenic factors, the source of which is industrial production, provoking man-made accidents and catastrophes, when assessing the quality of life of population. To fully take into account the factors affecting the quality of life of population, a comprehensive methodology created by the Council for the Study of Productive Forces by order of the Ministry of Economic Development of the Russian Federation that contains 19 indicators for diagnosing the quality of life of the population of the region, grouped by seven main areas, was chosen. Changes in the system of indicators of the consolidated index of the quality of life of the population under the influence of man-made accidents and catastrophes in the context of 7 spheres are shown. As an example, the impact on the main components of the quality of life of the population of the largest man-made disaster in the history of mankind and the nuclear industry - the Chernobyl accident - is considered.
\end{abstract}

\section{Introduction}

The technosphere, created thanks to scientific and technological progress, today, on the one hand, contributes to the formation of a huge number and variety of economic benefits that meet the growing needs of the population, and this, of course, leads to an improvement in the quality of life of the population. On the other hand, environmentally "dirty" and dangerous technologies used in industry, energy, utilities and other spheres of the national economy pose threats to the living conditions and health of the population and increase the risk of large-scale disasters.

We can identify the following reasons of man-made accidents and disasters:

\footnotetext{
* Corresponding author: kamdina_prof@mail.ru
} 
- irregularities in the operation of technical systems associated with manufacturing defects and violations of operating conditions;

- erroneous actions of the maintenance personnel of technical facilities;

- concentration of industries for various purposes without taking into account their mutual influence;

- external negative influence on energy and transport facilities;

- errors in the design of building, facilities etc. [1].

Man-made accidents and disasters are caused by the sudden failure of various units, machines and mechanisms during operation, which is associated with serious violations of the production process. They are also characterised by explosions, radioactive, biological and chemical contamination of big territories.

With the development of technology, the human factor, which manifests itself in engineering miscalculations, personnel errors and ineffective assistance from rescue services, plays a big role. The increase in the size and capacity of technical systems increases the risk of human, material and environmental losses. This is the price of the development of technology. Analysis of the causes of major accidents (according to UN data) shows that in most cases mechanical failures were their direct causes. An important cause of an accident is the human factor.

The number of man-made accidents and catastrophes on the territory of Russia over the past 20 years has almost three times exceeded natural disasters, according to the reports of the Ministry of Emergency Situations of the Russian Federation. Figure 1 gives data on the number of accidents and their causes in 2018 and 2019.

According to the data, given in Figure 2, it can be seen that the share of man-made accidents in 2018 accounted for almost $76 \%$ of the total number of accidents, while the share of natural ones is $18 \%$.

Living standards is a complex socio-economic indicator that includes the most important aspects of life, such as: the amount of income, the availability and quality of consumer goods, housing conditions, health and education, the provision of material goods, the quality of the environment, etc.

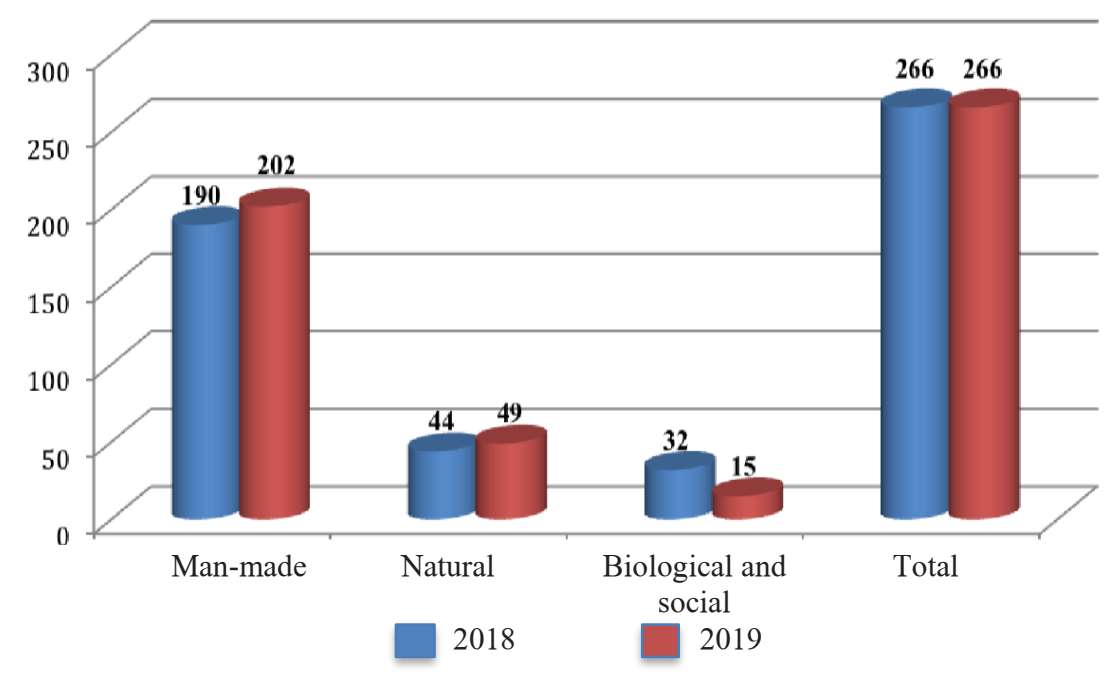

Fig. 1. Distribution of the number of emergencies in the Russian Federation by the reasons for their occurrence 
One of the factors that directly affect the living standards is the vulnerability of the population to threats from natural-technical and technical systems. Man-made disasters are accompanied by the loss of thousands of human lives, human health, property, income and irreparable damage to nature [2].

Statistics show that over the past twenty years, more than 3 million people have become victims of natural and man-made disasters, another 800 million people suffered, got injured or chronic diseases, lost property, material values and means of living.

In the Russian Federation, direct and indirect economic damage from emergencies of various kinds amounted, according to the Ministry of Emergency Situations, to 2\% of GDP per year - from 675 to 900 billion rubles [3].

Table 1 gives data about the number of disasters in the Russian Federation and caused property loss during the period of 2018-2019. [4].

The data of the Table 1 show that only for the last two years the property loss from disasters increased by $81 \%$ and in 2019 amounted to $20,507.88$ million rubles.

High rates of industrial production significantly enhance the impact of the energy component of the anthropogenic factor. An increase in the amount of $\mathrm{CO}_{2}$ emissions leads to an increase in the amount of greenhouse gases, which are one of the causes of climate change. The processes of climate change, launched in turn, contribute to the occurrence of large-scale disasters (floods, hurricanes, droughts, fires), causing colossal economical damage that cause an increase in mortality and spread of infections among the population.

Table 1. Quantity and property damage in the Russian Federation from accidents during 2018-2019

\begin{tabular}{|l|c|c|c|c|c|c|}
\hline \multirow{2}{*}{$\begin{array}{c}\text { Type of } \\
\text { accident }\end{array}$} & \multicolumn{2}{|c|}{ Quantity, pcs. } & \multirow{2}{*}{ Dynamics, \% } & \multicolumn{2}{c|}{$\begin{array}{c}\text { Property loss, million } \\
\text { rubles. }\end{array}$} & \multirow{2}{*}{ Dynamics, \% } \\
\cline { 2 - 3 } & $\mathbf{2 0 1 8}$ & $\mathbf{2 0 1 9}$ & & $\mathbf{2 0 1 8}$ & $\mathbf{2 0 1 9}$ & \\
\hline Man-made & 190 & 202 & 106.32 & $2,774.179$ & $4,751.476$ & 171.28 \\
\hline Natural & 44 & 49 & 111.36 & $8,317.826$ & $15,019.962$ & 180.58 \\
\hline $\begin{array}{l}\text { Biological and } \\
\text { social }\end{array}$ & 32 & 15 & 46.87 & 136.024 & 736.45 & 541.41 \\
\hline Total: & $\mathbf{2 6 6}$ & $\mathbf{2 6 6}$ & $\mathbf{1 0 0}$ & $\mathbf{1 1 , 2 2 8 . 0 2}$ & $\mathbf{2 0 , 5 0 7 . 8 8}$ & $\mathbf{1 8 2 . 6 5}$ \\
\hline
\end{tabular}

Over the past three years, the number of fires in the Russian Federation has increased by $12 \%$, the damage from fires amounted to 68.9 billion rubles [4].

Scientists of the Krasnoyarsk Scientific Center of the Siberian Branch of the Russian Academy of Sciences have determined that it will take from 60-100 years to restore forests after the Siberian fires. Moreover, in the course of long-term observations, scientists have found that as a result of climate change and the influence of anthropogenic factors, the time intervals between individual fires have significantly decreased to 5-15 years.

\section{Materials and Methods}

Anthropogenic factors that have a negative impact on the environment, on the health and living conditions of the population, for the most part, are associated with industrial production. Environment polluted as a result of anthropogenic activities, in turn, changes the conditions and quality of life of the population.

According to the authors, when diagnosing the quality of life of the population, the influence of anthropogenic factors, the source of which is industrial production, provoking man-made accidents and disasters, should be taken into account as a priority.

The analysis of methods for assessing the quality of life of the population [5-9] showed that the most complete coverage of the factors influencing the living standards and statistically controlled indicators is a complex methodology created by the Council for the Study of Productive Forces commissioned by the Ministry of Economic Development of 
the Russian Federation [10]. The methodology contains 19 indicators of diagnostics of the quality of life of the region, grouped by seven main areas. For each area, a composite index is calculated by combining individual indicators using a multidimensional average formula, and then seven indicators are linked into an integral indicator of the living standards. Table 2 shows the indicators for assessing the quality of life of the population, changing under the influence of man-made accidents and disasters [5,6].

Table 2. The indicators for assessing the quality of life of the population, changing under the influence of man-made accidents and disasters

\begin{tabular}{|c|c|}
\hline $\begin{array}{c}\text { Spheres of the living } \\
\text { standards }\end{array}$ & Change of indicators \\
\hline \multirow[b]{2}{*}{$\begin{array}{l}\text { 1. Revenue level of the } \\
\text { population }\end{array}$} & $\begin{array}{l}\text { Decrease in the consolidated income index of the population, due to an increase } \\
\text { in expenses for the restoration of household property }\end{array}$ \\
\hline & $\begin{array}{l}\text { An increase in the share of the population with incomes below the subsistence } \\
\text { minimum due to the loss of jobs, due to the complete/partial destruction of the } \\
\text { economic and social infrastructure }\end{array}$ \\
\hline \multirow{2}{*}{$\begin{array}{l}\text { 2. The level of } \\
\text { development of the } \\
\text { consumer market }\end{array}$} & $\begin{array}{l}\text { Decrease in retail trade turnover per capita due to a decrease in effective } \\
\text { demand, an increase in the share of food and non-food products imported from } \\
\text { other cities, regions, countries at higher prices }\end{array}$ \\
\hline & Increase in paid services per capita \\
\hline \multirow{2}{*}{$\begin{array}{l}\text { 3. Provision of the } \\
\text { population with housing } \\
\text { and the quality of housing } \\
\text { conditions }\end{array}$} & $\begin{array}{l}\text { Reduction of the total area of residential premises per } 1 \text { inhabitant due to the } \\
\text { complete/partial destruction of the housing resources }\end{array}$ \\
\hline & $\begin{array}{l}\text { Reduction in the composite index of the improvement of the housing resources } \\
\text { due to the destruction of infrastructure (breakage of power lines, damage to } \\
\text { pipelines, water pipelines, etc.) }\end{array}$ \\
\hline \multirow{2}{*}{$\begin{array}{l}\text { 4. Provision of the } \\
\text { population with material } \\
\text { benefits }\end{array}$} & $\begin{array}{l}\text { Decrease in the number of own cars due to their complete/partial loss (floods, } \\
\text { fires, explosions etc.) }\end{array}$ \\
\hline & $\begin{array}{l}\text { Decrease in the number of personal computers and other household appliances } \\
\text { due to their complete/partial loss }\end{array}$ \\
\hline \multirow{2}{*}{$\begin{array}{l}\text { 5. Level of development of } \\
\text { health care and education }\end{array}$} & $\begin{array}{l}\text { Insufficient provision of doctors and outpatient clinics in the event of large-scale } \\
\text { disasters with numerous victims }\end{array}$ \\
\hline & Complete/partial destruction of educational facilities and their property \\
\hline \multirow{3}{*}{ 6. State of the environment } & $\begin{array}{l}\text { Increased emissions of pollutants, incl. radioactive as a result of accidental } \\
\text { releases, explosions, fires, gas leaks }\end{array}$ \\
\hline & $\begin{array}{l}\text { An increase in the discharge of pollutants into water sources, as a result of } \\
\text { accidents on oil pipelines, leaks of oil, chemical and radioactive substances by } \\
\text { industrial enterprises }\end{array}$ \\
\hline & $\begin{array}{l}\text { Increase in soil pollution with chemical, toxic, radioactive compounds as a } \\
\text { result of rupture of pipelines, oil pipelines, etc. }\end{array}$ \\
\hline \multirow{2}{*}{$\begin{array}{l}\text { 7. Labor market conditions } \\
\text { and migration } \\
\text { attractiveness }\end{array}$} & $\begin{array}{l}\text { Increase in unemployment due to complete/partial destruction of the economic } \\
\text { infrastructure }\end{array}$ \\
\hline & $\begin{array}{l}\text { Reduction of the coefficient of migration attractiveness of the region due to a } \\
\text { large-scale environmental disaster, the destruction of economic and social } \\
\text { infrastructure }\end{array}$ \\
\hline
\end{tabular}

\section{Results and Discussion}

Let's consider the impact on the quality of life of the population of one of the largest manmade disasters - the accident at the Chernobyl nuclear power plant. The fire that occurred as a result of the explosion led to the release of radioactive materials into the environment. In composition, these were radioactive gases, condensed aerosols and fuel particles. The total activity of radioactive substances was about $14 \mathrm{EBk} 5$, including $1.8 \mathrm{EBk}$ of iodine$131,0.085 \mathrm{EBk}$ of $137 \mathrm{Cs}, 0.01 \mathrm{EBk}$ of $90 \mathrm{Sr}$ and $0.003 \mathrm{EBk}$ of plutonium radioisotopes. About half of the total emissions were noble gases [11].

The impact of the consequences of the disaster on the level of income

Before the disaster, the main source of income for the inhabitants of the region was agriculture, which, in fact, is a low-paid industry. As a result of the accident, many 
enterprises were closed, as restrictions were imposed on agricultural production related to the need for constant radiation monitoring. Additional restrictions, costs and reputational losses (products from the infected territories were not in demand in other regions or countries) caused damage to the agricultural sector. The already low incomes of the population after the disaster fell sharply against the background of high unemployment (after the closure of enterprises), which led to an increase in the level of poverty in the contaminated areas.

The impact of the consequences of the disaster on the level of healthcare

This man-made disaster led not only to death of more than 400,000 people, but also to a big number of irradiated people both on the territory of the NPP and in neighboring regions.

Subsequently, many victims of radiation became disabled, the growth of oncological diseases (cancer of the thyroid gland, leukemia), diseases of the cardiovascular system increased significantly. As a result, the mortality rate increased, the average life expectancy and the birth rate decreased.

The impact of the consequences of the disaster on the quality of the environment

The ecosystem suffered devastating damage - radionuclides polluted not only the air, but also the soil, surface and ground waters, plants and animals. In the future, they got into the human body with food and water, leading to re-infection.

The impact of the consequences of the disaster on the state of the labor market and migration attractiveness

The share of small and medium-sized enterprises in the affected areas has decreased, as many qualified and educated workers have left the region. The volume of private investment decreased due to the low reputation of the region, as well as due to the difficult conditions for entrepreneurship in general [11].

\section{Conclusions}

1. In their study, the author offered to take into account the influence of anthropogenic factors, the source of which is industrial production, provoking man-made accidents and catastrophes, when assessing the quality of life of population.

2. To take into account the factors influencing the quality of life of the population, the complex methodology created by the Council for the Study of the Productive Forces was chosen as the basic methodology.

3. The system of indicators of the quality of life of the population has been supplemented taking into account the factors of the impact of industrial accidents and disasters.

4. The impact on the quality of life of the population of the largest man-made disaster in the history of mankind and the nuclear industry - the accident at the Chernobyl nuclear power plant - is considered.

\section{Acknowledgements}

The study was carried out with the financial support of Izhevsk State Technical University named after M.T. Kalashnikov in the framework of the grant agreement No. CAC/20-20-10

\section{References}

1. S.S. Timofeeva, Methods and technologies of evaluation of risks of emergencies: practicum, 75 (2015)

2. Ya.V. Sychev, Internet magazine Technosphere Safety Technologies, 1(41) (2012) 
3. Statistics of emergencies during the last 10 years, https://domjurista.ru/

4. State report "On the state of protection of the population and territories of the Russian Federation from natural and man-made accidents in 2019" (2020)

5. I.S. Belik, L.V. Kamdina, Economic of the region, 15, 4 (2019)

6. I.S. Belik, L.V. Kamdina, Bulletin of Chelyabinsk State University, 7(417) (2018)

7. Zuzana Hajduová et al., Contemporary Issues in Business, Management and Education 2013 Procedia - Social and Behavioral Sciences, 110 (2014)

8. S.A. Ayvazyan, Integral indicators of the quality of life of the population: their construction and use in socio-economic management and interregional comparisons, 98 (2000)

9. V.F. Bezyazychny, E.V. Shilkov, Quality of live: manual (2004)

10. I.V. Grishina, A.O. Polynev, S.A. Timonin, Modern productive forces, 1 (2012)

11. The legacy of Chernobyl: medical, environmental and socio-economic implications and recommendations to the governments of Belarus, the Russian Federation and Ukraine. Chernobyl forum: 2003-2005 (2005) https://www.who.int/ionizing_radiation/ 